\title{
Hunting paths in the Amazon: technics and ontogenesis among the Panará
}

\author{
Fabiano Campelo Bechelany' \\ 'Universidade Federal do Sul e Sudeste do Pará, \\ Faculdade de Ciências Sociais do Araguaia-Tocantins, Marabá/PA, Brasil
}

\begin{abstract}
This paper presents a description of hunting and an analysis of its technical relations among the Panará, an indigenous group which inhabits southern Amazonia. The paper is focused around two genetic processes of hunting: the individuation of the hunter and the constitution of a hunting territory. In this sense, it approaches the constitution of the hunter as person in relation with his weaponry, a technical object that is the mediator between the hunter's action and the prey; afterwards, it approaches the forms of environment that emerges from the movement across the forest and through the production of hunting paths where the prey is encountered. The analysis of these aspects allows us to get insight of the hunting activity from the point of view of its actions, materials and interactions with the environment, from the analysis of technical elements which are socially relevant and construct important modes of relation between Panará and their territory.
\end{abstract}

Keywords: hunting; technical object; person; environment; Amazonia. 


\section{Caminhos de caça na Amazônia: técnica e ontogênese entre os Panará}

\section{Resumo}

Este trabalho apresenta uma descrição da caça e uma análise das relações técnicas entre os Panará, grupo indígena que vive na Amazônia meridional. O texto tem como foco dois processos genéticos da caça: a individuação do caçador e a constituição de um território de caça. Nesse sentido, aborda a constituição da pessoa do caçador em relação à sua arma, um objeto técnico que é o mediador entre a ação do caçador e a presa; na sequência, aborda as formas do ambiente que emergem do movimento pela floresta e através da produção dos caminhos de caça onde a presa é encontrada. A análise desses aspectos nos permite adentrar a atividade da caça do ponto de vista das suas ações, materiais e interações com o ambiente, a partir da análise dos elementos técnicos que são socialmente relevantes e que constituem modos de relação importantes entre os Panará e seu território.

Palavras-chave: caça; objeto técnico; pessoa; ambiente; Amazônia. 


\title{
Hunting paths in the Amazon: technics and ontogenesis among the Panará
}

\author{
Fabiano Campelo Bechelany \\ "good hunting causes good pain" \\ An old hunter, quoted by Kenneth Kensinger, On meat and hunting.
}

\section{Hunting and technics}

A tiring activity, hunting is also a source of pleasure for hunters, of aesthetic and corporeal experiences. When they hunt, the Panará claim that they are going for a walk in the forest (suasêri). Walking is a creative movement through which animals and prey occur for a hunter. Tracking and following animals through the forest is one of the many varieties of hunting practiced by the Indigenous and traditional peoples of Amazonia. For the Panará, who live in southern Amazonia, walking through the forest is one of the ways that they come to know and engage with the forest. Despite the contemporary role of other forms of hunting - ambushes from high fruiting trees, nocturnal hunting along the rivers by boat, or hunting at the fringes of the soy plantations that border the Panará Indigenous Territory - a hunter perambulating, bearing his weapon, chasing terrestrial or arboreal prey such as peccaries and spider monkeys, amounts to a specific way of existing for the Panará.

Current anthropological discourse on the practices through which humans, animals and the environment relate to one another provides the groundwork for an analysis of hunting that extrapolates its mere economic and subsistence base toward other processes that stem from hunting activity. Thus, hunting is an activity where multispecies relations (Kirksey and Helmereich 2010; Kohn 2013) are lived, configuring one of these practices that Marisol de la Cadena (2015), along with other authors, calls "worlding"; that is, practices woven in and through the earth, constituting the places by means of which hunting peoples live ${ }^{1}$. It is, equally, an event where multiple points of view converge, as formulated by Eduardo Viveiros de Castro (1996), Tânia Stolze Lima (1996), and others. It is the activity wherein the predicates of Amazonian relational ontologies are distributed, and in which perspectivism is anchored in diverse cosmologies (cf. Lagrou 2018; see Kohn 2015).

Attention to Amazonian regimes of sociality leads us to find, in the hunt, forms of relating that are distributed in other fields of Indigenous life, such as warfare and shamanism. But if hunting is central to Amerindian sociality, we have yet to investigate the actions that constitute it, thereby following a set of practices through which these human groups inhabit the world. If hunting is a way of living and doing on earth, we must investigate what are the means by which this experience occurs. Hunting would thus be a part of Indigenous regimes of territoriality. To approach these regimes by way of the hunt, we should enquire into how hunting makes possible an experience of territory while, at the same time, constituting the people and the group who inhabit this space.

To approach this theme, I analyse in greater detail aspects of the hunt which point to the complexity of the relations between hunters, animals and forest. I thus ask: what are the operations of hunting? How does the relation between a hunter, his weapon, the animal prey and the different elements that compose the forest proceed? Which gestures are carried out and what bodily dispositions are activated in carrying out hunting activity? What are the material bases of the hunt which unfold into the set of perceptions and formulations about hunting activity?

\footnotetext{
1 According to the author: "practices that create (form of) being with (and without) entities, as well as the entities themselves. Worlding is the practices of creating relations of life in a place and the place itself" (De la Cadena 2015: 291).
} 
In this article, I engage these questions through an ethnography carried out along the hunting paths ${ }^{2}$. Analytically describing the skills, perceptions, gestures and technical objects used, I approach the material and operational elements of the hunt among the Panará. I will deal with two dimensions of the activity: the relation between the hunter and his weapon, the technical object that constitutes the person of the hunter and enables capture; and the ways that hunters walk along and interact with the forest environment, generating a space which assume the form of hunting paths.

Considering the importance of hunting for a range of human groups in Amazonia and elsewhere, there are also different ways of approaching it. In this article I establish an ethnographic dialogue with some of the approaches of the anthropology of techniques, focusing on questions that have only been marginally addressed in other work. I will investigate how the hunter acts through gestures, movements and objects that place him in interaction with animals and the forest environment. The questions I raise thus answer not so much why the Panará hunt, but how it is like to hunt with them: what happens in the relation between hunter and prey, within the space of the hunt (c.f. Marvin 2010).

One of the main aspects of the anthropology of techniques developed by distinct traditions (Coupaye and Douny 2010), is attention to the transitive actions between the body, artefacts and the material world. Material operations are constitutive of vital processes and of human insertion in the world, as André Leroi-Gourhan illustrates in his work (1984a [1943]; 1984b [1945]; 1990 [1964]; 2002 [1965]). In this way, we can claim that the anthropology of technique, like the anthropology of action (Ferret 2014) - of the ways of operating - allows us not only to understand the specificity of an activity, but also the ways that humans produce and reproduce themselves.

A technical act is a configuration of movements and materials, in which things, environments and subjects participate (cf. Lemmonier 1992). As an analytical category for a relational modality, technique does not approach the activity of the hunt via classifications of the different varieties of the activity - the "hunting techniques" which are common in manuals and descriptions of ecological relations. Rather, apprehending the hunt as technique invites us to penetrate the operations and elements of each one of these categories, as in persistence hunting or in hunting with traps, for example, and to thereby observe things and movements in relation, and to follow how hunters, animals and forest are constituted in the process. Hunting emerges as "a mode of being, a system of coordinated actions that emerge concomitantly with the regimes of individuation, including that of humans" (Sautchuck 2019:182).

By "individuation" I refer to the genetic/creative process wherein the human, the animal and the artefact acquire properties of the system in which they participate. To enquire into how they act, how they function, or how they operate, is to observe how they individuate in the process. To not consider them not as given elements, but as effects, or as being in individuation, is an ontogenetic perspective that we encounter in Leroi-Gourhan's anthropology of techniques, or in Gilbert Simondon's (2005; 2017) philosophy. Among Simondon's many contributions, I here make use of the idea that individuals (humans, animals) are derivations of a tense system, unstable realizations, where the ensuing problem is maintaining a unit, the most important characteristic of which is its functional autonomy, and not its morphological unity (Simondon 2005; cf. Sautchuk 2015). The ontogenetic process suggested by Simondon allows us to accompany how the hunter, a person with social attributes for the Panará, results from an ontogenetic process the properties of which are generated by the articulated action between a weapon and an animal. The Panará say that this person is a suaseriantê, a "walker", as we will see in this article.

\footnotetext{
2 This text derives from and develops my doctoral thesis (Bechelany 2017a), which results from ethnographic fieldwork carried out with the Panará since 2013. I thank the Panará for their hospitality and for taking me through the hunting paths. I also thank my thesis examining committee for the opportunity to discuss my work, and my colleagues at the LACT and T/terra at the UNB, as well as in other places and events. I also thank the Brazilian agencies that funded my research during different stages, in particular the CNPq and CAPES.
} 
Considerations pertaining to the technical structure of the hunt connect to other aspects of the social life of hunting peoples. Hunting is an activity that articulates with numerous dimensions, such as feeding and the economy, kinship and warfare, ritual and shamanism (cf. Garcia 2016; Shepard 2014), which makes defining it always difficult. Symbolically salient among the Indigenous people of lowland South America, it operates through differentiators between humans and animals (Fausto 2007; Descola 1998), or gender relations (Taylor 2001). By proposing to study hunting as technique, I do not intend to adopt an instrumental or practical determinism, but to recognize the concatenation of operations and multiple causes, observing which agents, materials and events participate in the activity. I believe that this approach aligns with that of other authors (cf. Coupaye 2015; Mura 2011). In a recent article, Ludovic Coupaye and Perig Pitrou (2018) enumerate a set of questions involved in a technical approach, with an emphasis on the relevant effects for the (collective and individual) agent (2018: 07):

(1) It allows to concurrently tackle patterned practices of making and using without grounding our analyses on Modernist economic paradigms of 'production' or 'consumption', which imply a productivist frame; (2) it remains empirically grounded, allowing the attention paid to actions performed and how they are evaluated, imagined, and discussed; (3) it reasserts the ways in which time (temporality, velocity, rhythmicity) and spaces (workshop, gardens, hunting ground, sea) are both created and striated by the ways in which actions are performed and experienced; (4) by shifting scale, it also allows the revealing of the role of many other analytical domains such as kinship, politics, religion, cosmology, exposing how any technical process are profoundly heterogeneous and ontogenetic.

Heedful of these elements, I now turn to an empirical approach that also contributes to conceptual and descriptive opening up of the hunt in varied contexts. This opening up complements already-consolidated descriptions of the "venatic ideology" (Viveiros de Castro 2002), which foregrounded the hunt in ethnographic theories of Amazonian 3 . In this article I thus investigate the forms of action in the Amerindian universe that add to the theories of its symbolic forms.

\section{The social life of hunting among the Panará}

The group that calls itself Panará, made up of some 600 people, currently lives across the Brazilian states of Mato Grosso and Pará, in five villages distributed along the Iriri River and one of its tributaries, the Ipiranga River. Both rivers are formed in the Cachimbo Hills and flow north into the Xingu River, after traversing the Panará Indigenous Territory and other Indigenous Territories and Conservation Units. The region is covered by a vast forest, with an abundance of flora and fauna, making up the rich corridor of sociobiodiversity of the Xingu.

In the early 1970s, after the BR-163 highway tore through the group's lands, causing death and social chaos (Batista de Lima and Bechelany 2017), the Panará were forcibly removed from this region and taken to the Xingu Indigenous Park (Parque Indígena do Xingu, PIX). The Panará arrived in the Xingu barely existing as a group, and were confronted with a new reality, with new social groups, goods and practices, new political relations and a different environment ${ }^{4}$. The plasticity of Panará ecological relations allowed them to develop subsistence activities - albeit with setbacks and despondency (Schwartzman 2010). The desire to return to their original territory remained, and 25 years later, in the mid-199os, they finally succeeded (Arnt et al. 1998).

\footnotetext{
3 In an earlier study (Bechelany 2012), I analysed ethnographic discourse alongside anthropological data of Amazonian hunting. The observations of Glenn Shepard (2014) and Uirá Garcia (2016) on the theme provide an important panorama.

4 The ecosystem of the PIX is characterized as a transition zone between Amazonian forest and savannah, and is therefore distinct from the open rainforest of the area further north that they formerly occupied, where nut trees, açai palms and small watercourses are predominant.
} 
The return to the "good land" was followed by a significant population increase. The village of Nãsêpotiti, where I carried out most of my fieldwork, is currently bursting with children and young people. Men and women born in the new village divide themselves among activities in the local school, and tasks such as gardening, playing football, chatting in the village centre, hunting and fishing. Among the Panará, hunting is a male activity. Boys soon start to accompany older men from their families in the hunt. As they gain generational independence and domestic autonomy, they begin to hunt with partners. When they reach the mature phase, when they became heads of a household, they hunt alone, or with their small sons. Women, in turn, do not hunt, but can eventually accompany their husbands, although this is increasingly rare.

There is a complementary relation between men and women which is synthesized by the Panará in the phrase: "men hunt, women prepare kiampo". Kiampó is a Panará dish, common among other Jê-speaking peoples, made from maize or manioc roasted in traditional earth ovens, a sophisticated method of cooking for people who rarely had ceramics. ${ }^{6}$ Upon leaving their houses for a hunt, or for fishing large fish, the couple begins, separately but complementarily, the preparation of the nocturnal meal. Women start to process available manioc or maize, in a process that will conclude at the end of the day with the heat of the burning logs and the stones that make up the hearth. In general, this meal extrapolates the nuclear family, and the amount of kiampó prepared allows for distribution among the domestic units linked to the house'

This varies seasonally, according to the scarcity or abundance of animals. Although they hunt all year round, the best tasting meat is to be found when the animals are fat (ntuma), which is when the rains increase (intaa pori) and the animals circulate through the forest between flooded land and amidst abundant fruiting trees. During this period, Panará gardens provide little food, and a part of the group camps in the forest in anticipation of the large rituals. During the dry season, game animals are lean and during the height of the season the Panará fish with timbó poison in dammed areas of the river, which produces an abundance of fish. The cycles are complemented in different combinations. When the waters of the river fall, the tapirs come to the great Kôtunsi lake to cool off. This area, some two hours on foot from Nãsêpotiti, is a favourite spot for ambushing tapirs and other prey, as well as being abundant in fish.

The Panara diet is not very restrictive in terms of what animals can be eaten. In the past, caimans and capybaras were considered contemptible, while tapirs, deer and peccaries were favoured game meat, consumed along with others, such as armadillos, monkeys and birds, particularly Cracidae (guans and curassows). During liminal phases, various conditions of restriction, and illness, people avoid the meat of large mammals and catfishes, for instance, although each has specific shamanic determinations. As in much of Amazonia, the Panará view the consumption of meat as a risky endeavour due to the agentive properties of the corporal material of the animals, which can be a subject in different situations (Costa 2012; Hugh-Jones 1996). Large mammals display these conditions with greater potency.

The hunter refrains from eating the meat of animals that he has hunted, lest he become ill or see his interactions with living prey become affected by the relations that dead prey maintain with other members of the species. Numerous restrictions take place here. Experienced hunters warn younger hunters to only ingest specific parts of the animal or risk acquiring undesirable properties from it. Thus, one avoids eating the paws or body parts of the tortoise (Chelonoidis denticulata) so as to not become slow like the animal. This is somewhat similar to the widespread panema complex (Almeida 2013, DaMatta 1973; Garcia 2012b), which curses the hunter with his greatest threat: the unfortunate non-encounter with prey. Among the Panará, the improper

\footnotetext{
Called berarubu or paparuto in other regions (as among the Timbira, for example).

See description in Bechelany (2017a).

The meat-fish-kiampó association is the materialization of the "community of substance" that the domestic units, and those related through affinal ties, constitute. Meat and kiampó are the foodstuffs imbued with significant symbolic and social weight, being, in general, the food of kinship, eaten with and as kinspeople (on this issue, see the vast discussion in Amazonian anthropology: Coelho de Souza 2002; Fausto 2007; Gow 1989; Vilaça 2002).
} 
consumption of the animal can result in a state that affects the hunter, making him a suanka. A person who is suanka, which the Panará at present translate as "lazy" (preguiçoso) is downcast, lacking disposition. Contact with the menstrual blood of his companion can also generate this state in the hunter.

The opposite of the suanka condition is the suakin state. Hunters who wake up early to go to the forest are suakin a hê, well-disposed, and are so viewed by the rest of the village. Elizabeth Ewart $(2005,2013)$ analyses both notions as "psycho-physical states" that characterize intersubjective availability and sociability. Moreover, suakin and suanka are dispositions that transmit the capacity to affect and be affected by others. They are relational modes that increase or decrease a person's capacity to act. It is in the suanka state the men organize for the hunt. In the early morning, they get their rifles. With scarce food in their bellies to activate their will and to leave their body light, they walk away from the village, or cross the river in canoes and boats to reach the other shore, where they disappear into hunting paths.

\section{The hunter's weapon and body}

Along with the psycho-physical states of the person, which are constitutive of the conditions for the hunt, entering the forest demands other aptitudes that propitiate the appropriate interactions. One of these is the use of weapons, which confer on the hunter the capacity to capture animals. A short tale, narrated by my Panará friend Sinkú, introduces us to this issue.

One time, Sinkú and two other friends docked their boat on the banks near the forest, and entered the area looking for some fruit to eat. After walking for about ten minutes, they heard a herd of white-lipped peccaries (Tayassu pecari) eating inajá fruit. Without weapons, they decided they needed to leave, but before retreating they were surprised by the peccaries. Having no means to defend themselves, they looked for a high point which could not be reached by the animals. Unable to carry out an offensive act, they climbed trees and waited, watching the animals thundering their jaws, cornering the men like prey. They had to wait for a long time before their predators gave up and left, allowing time for the hunters to leave as quickly as they could.

The tale is trivial, and similar incidents can happen in different situations. However, it includes an inescapable fact for the Panará: a man becomes a hunter with a weapon in his hand. The Panará express this in many ways. On another occasion, walking with a group of women toward a garden, I was told to go in front since I was the only one with a rifle (women do not handle rifles), and was therefore the only one capable of defending them from a jaguar, if one were to show up - as the woman who was at the head of the queue told me somewhat ironically.

If a hunter goes hunting, it is assumed that he will carry a weapon. In many situations in which I was present, complaints about the scarcity of meat became more intense in the village. Men would often justify this state of affairs by saying that they were not hunting because they had run out of ammunition, which made their firearms useless in the dense forest. Men would generally take a rifle whenever they left the village, even if, for example, they were only going to the garden, or to look for one resource or another in the forest, or to travel by boat to another village.

The Panará adopted firearms, "things of the whites" (ipẽ jõ soti), when they lived in the PIX, acquiring their first rifles through exchange or as gifts from FUNAI ${ }^{8}$. Having returned to the area where they now live, they acquired greater numbers of firearms, much through resources obtained from reparations for damages caused

\footnotetext{
8 Fundação Nacional do Índio (National Indian Foundation). During the 1970 and 1980 os Funai would periodically donate items to Indigenous peoples, in an assistentialist practice that sought to equip them to survive in a post-contact environment. The way that Funai related to the Panará (and various other Indigenous groups) is considered, by the Panará, as a time in which "Funai was strong", in opposition to the current moment in which a "weak Funai" no longer donates goods. The change in policy is moving towards a phase in which "projects" become more important, and where goods and resources are obtained through articulations not only with Funai, but also with non-governmental organizations.
} 
by the construction of the BR-163 Federal Motorway9. Mature hunters, born in the PIX, claim to have learned how to hunt with firearms. Bows and arrows, which were used before rifles, are still produced frequently. They are used for fishing, particularly with timbó toxins. Bows and arrows are also sold by the Panará in areas outside of the village. They are also carried during different ceremonies.

Firearms are male property, and they are valuable. One who lends a firearm to a hunter will receive a share of the hunt. A crucial aspect of hunting with firearms is access to ammunition, which can be acquired in town. Their high price places limits on the use of rifles and, consequently, on hunting. Part of the financial resources of men are used to by ammunition, along with fishing lines and hooks.

The fact that firearms necessarily tie hunting to the world of the whites - via the acquisition of firearms and their upkeep, and because of the need to acquire ammunition - has meaningful effects for the Panará. Analysing a similar phenomenon among the Wajãpi, Pierre Grenand (1995) finds homologies between the control of, negotiation or alliance with spirits considered owners or masters of animals and those established with the whites, owners of hunting firearms. However, this perspective remains anchored in analysis of the effects and meanings of the circulation of the rifle, as well as in the production of these objects, as is the case, in general, for the study of artefacts in Amazonia, whether as material culture or in less "materialist" studies, such as in the volume The occult life of things, edited by Santos-Granero (2009). How things actually work remains an analytical black box.

I have elsewhere carefully analysed the properties of the hunting weapon that emerge from its quality as ipe $j \tilde{o}$ soti, "thing of the whites" (Bechelany 2017a; 2017b). The circulation and use of firearms is important, but if we want to understand what happens during the hunt we need to ask how they work, what their "functionality" (Sigaut 1991) is, and how they mediate the relation between hunter and prey.

One way of approaching these issues is through Leroi-Gourhan's (1984a, 1984b) writings on the technical object, particularly the attention he draws to the energetic economy that relates body to artefact, demanding a specific performance. The interaction between the hunter and his weapon cannot be readily understood within the terms of the subject/object opposition, as two incompossible realities; rather, it is a systematic relation, like making a body, walking together, or an individuation. The individuation is needed in order to assume a position - that of a hunter rather than prey - and to determine modes of acting during the hunt.

The way that a weapon, as a technical object, acquires properties and affects the engagement of the hunter during the hunt implies specific agencings. One of them occurs in the spatial and perceptive orientation of the hunter as he moves through the forest. As he walks, the hunter considers the position of his weapon to guide him through the forest. Hunters told me not to touch the barrel of the shotgun, to always leave it to one side of our bodies, allowing the shotgun to guide us along the way. They say that the side on which the shotgun rests manoeuvres the hunter to circle the forest, guiding him to always walk towards the same side, taking him back to the point from whence he started off. This compass-condition of the weapon is associated with the hunter's perception of movement, making the weapon contiguous to his body.

In this interaction between object and person, the two should not be taken as given entities that interact. If we observe the way they operate, we see the constitution of the terms through processes that are articulated. François Sigaut (2008) stresses the transitive character of this use of technical objects in analysing "instrumental" gestures (geste outillés), in which it is not only the instrument that prolongs the gesture, but the body itself that needs to be "instrumentalized" upon executing certain movements. In this sense, the hunter-weapon relation is not like a bodily prosthetics, extensions of bodily actions, but, rather, instruments and their functionalities

\footnotetext{
9 The Panará won a court case, in which the Núcleo de Direitos Indígenas (Indigenous Rights Nucleus) were the plaintiffs, in which the Panará held the state responsible and demanded reparations for the material and moral damages caused by Funai and the Brazilian army during the construction of the BR-163. After a lengthy process, the court demanded that the State and Funai pay indemnities, which were deposited in the name of the Panará Iakiô Association, in the first years of the 21st Century (see Batista de Lima e Bechelany 2017).
} 
act on the body and alter gestures and perceptions. An analysis of gestures allows us access to the operational behaviour implied in hunting.

\section{Technogenesis of the infallible gesture}

As I have been claiming, the body-weapon conjunction constitutes a dimension of the process of individuation of the hunter as an agent capable of killing. However, a parallel and temporally distinct process is also recognized by the Panará as having efficacy in the hunt: care in the generation of properties of the body that confer effective movements and gestures. More specifically, the Panará seek to generate properties in the arms of the hunter so that his shooting will be precise. These properties result from processes of fabrication and perennial care, which are consonant with the well-known Amazonian emphasis on the social production of bodies and peoples, which comprise the sociocosmological basis of Amerindian societies (Seeger; DaMatta; Viveiros de Castro 1979).

The fact that a hunter is preparing to kill an animal is a presupposed effect of his formation and learning. But if every hunter learns to carry out a set of gestures so as to realize an effective act, there are those who are capacitated to do so in a more precise and efficient manner. These differentiations are part of the competitive relations that hunters weave during their hunt, in a joking manner or as bets ${ }^{10}$.

The recognition of a man's skills, dexterities and cunning is part of male social value. These qualities derive from various sources. It is generally understood that experience is an attribute, and the elderly are skilful hunters. Hunting skills are knowledge generated in practice and they are related to the adequate bodily dispositions and the perceptive field of the hunter, which makes them similar to Tim Ingold's (2000) notion of 'skill'. As he has argued, the perceptive field developed in the forest is directly tied to a communicative modality between hunter and animal. The capacity to perceive the tracks of animals and to compose a system of information between events that happen in the forest is part of this dexterity. For Panará hunters, this skill is also an effect of processes that occur in other spatio-temporal dimensions, such as in dreams and in shamanic séances.

Among bodily properties, the Panará emphasise skilful gestures; in this case, the organ of the body that carries out the action can undergo treatment so as to carry out its gesture. Until the recent past, the Panará made incisions in the articulations of the arm using harpy eagle (sypakâkâ) claws to inscribe in the body the properties of this animal, in particular potency and precision with the bow and arrow. Most men over 35 years of age have these incisions, which were made by experienced hunters. The claws of the harpy eagle (Harpia harpyja), an apex predator, were used to perforate wrists and elbows, causing bleeding. These parts of the arm are important for firing arrows, since the wrist performs pulls the string, while the other arm, stretched out, moves the bow forward. The required strength is concentrated in these muscles and articulations, and the incisions, the Panará tell me, were made to strengthen the arm. This operation, linked to propulsive movement, force and energy, was carried out to elicit an infallible gesture, which the call pámpé.

The main operational principle of the incision is pain $(s \hat{a})$, which transmits the qualities inherent to the claws of the harpy eagle. The notion of pámpé designate the real, good, unerring (impé = 'true') arm (pá). It is opposed to the notion of pákian, which designates the 'mistaken arm', which does not aim true. According to Schwartzman (1988: 199-200), pain-inducing applications transferred strength to an arm (si tâti a hê = to make strong). I suspect that they had a wider application, not restricted to the sense of physical pain, but also of

\footnotetext{
10 Bets among hunters, the Panará claim, is a recent practice, which they learned from neighbouring peoples and which derives from football competitions held in the village. Bets are common in all sorts of activities that can acquire the characteristics of a game or a dispute between two adversaries. It can feature during fishing, hunting, dominoes, of card games in the village centre. The exchange of goods that results from these competitions is one of the main motivations of these bets.
} 
precision. The infallible gesture is also one which does not falter, that does not sway when it is time to take the shot, but which is precise and thorough, striking prey. This are determining properties if we consider the set of bodily operations at this moment. One's arm and body must be steady and firm when the projectile is fired (from a shotgun or a bow), preventing any involuntary movement that can interfere in the projectile's trajectory.

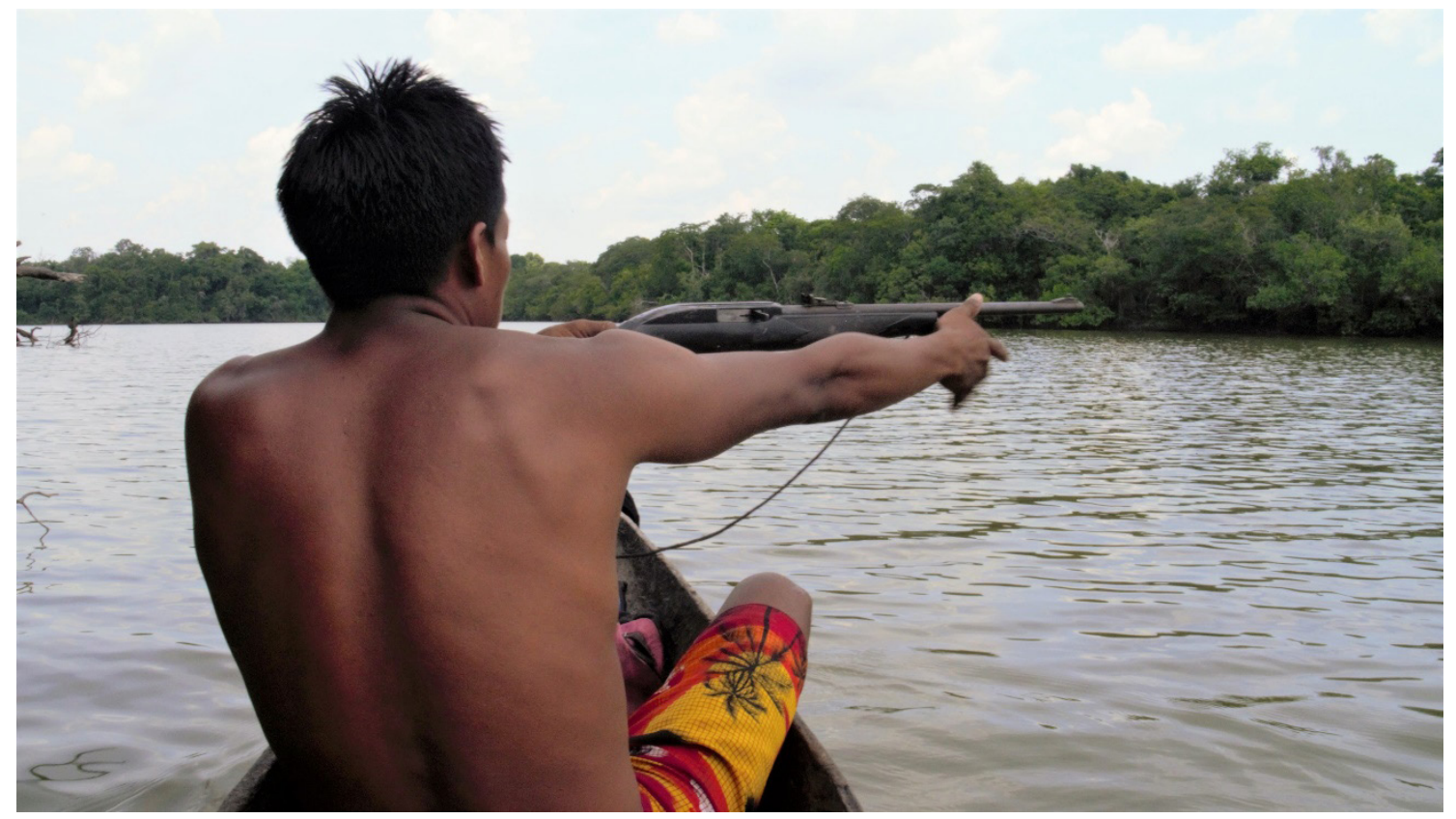

Kierãsa, balancing in a canoe, aims his shotgun towards prey on the shores of Kôtunsi Lake.

(Photo by the author)

In what pertains to the skill of the pámpé gesture, it results from knowledge also obtained by the intervention of magical practices that can interfere with material action. The pámpé, as a skill for a precise, unequivocal action, refers to a gesture that is not only the fruit of a knowledge of the mechanical operations that need to be executed, but of establishing relations between heterogeneous elements that generate effects. Hence other actions should also be observed for the gesture to be precise. In order to have a good hand during the hunt, for example, it is necessary to avoid fondling male genitals - though not the genitals of one's sexual partner.

Although incisions are no longer applied for the use of the shotgun, they were instigated by the realization of the appropriate gesture for the use of the bow, which implied an action of the hand, the pulse and the articulations. Perhaps because of the changes in the mechanism of the weapon, incisions on these areas have become obsolete. But the pampé gesture is still seen to be the centre of the skills of the hunter - the relation of the arms with the weapon capable of launching the projectile with precision. 


\section{Technical Transformations}

The Panará hunt has undergone various changes over time. The one that occurred to its arsenal, however, allows us to investigate how technical transformations cannot be evaluated as mere ruptures or substitutions. Bows and arrows and firearm $s^{11}$ function within a wider technical set and, therefore, their functioning within this set is not determined by materiality, or by their structure, but by the conjunctions created by each weapon. The shift from the use of the bow and arrow to the use of firearms, an incomplete historical process, results in change as much as in significant continuities in the technical system. Transformations also enabled the differences between the weapons to operate in tandem with other elements, and thus to preserve relational modes between animals and the hunter. In any case, the strategic act of launching a projectile at some distance remains central to the mode of existence of Panará hunting weapons.

The differences in hunting techniques and the weapon used for hunting can be treated, by both thought and practice, as distinct relational modes, mediating beings, distance and diverse interactions. In Amazonia the range of weapons used for hunting create differential effects in how the hunter relates to the animal and the type of operational behaviour involved. Laura Rival (2012) defined this with precision. Revisiting her former work (Rival 1996), which pioneered the theme in the region, she writes:

Hunting with a blowpipe and with a spear are two entirely different ways of socializing the environment and domesticating nature. More importantly for the argument developed here, these two forms of hunting embody two different ways of engaging and knowing forest's ecology, and of using the signs that are internal to biological dynamics (Rival 2012: 135).

In the Panará context, the change effected by the shotgun as a technical object for movement and transport is simply the development of something that is already an aspect of the bow and arrow: the launching of a projectile at a distance. That the projectile launched from a shotgun travels faster and farther is not a minor detail, but in terms of what it does to the freedom of the body of the hunter it is quite similar to an arrow. One mechanism, however, makes it differ: the origin of the propulsive force. While the arrow depends on transferring the strength of the body to the mechanism of the bow that will launch it, for the shotgun propulsion is generated by a physio-chemical mechanism that results in an internal explosion which creates a force that fires the projectile. This, for sure, effects changes in the associated gestures. The transferral of strength, I believe, is one of the reasons that the harpy eagle claw-incisions on the hunter's arms have been abandoned. The change makes the practice redundant, but it transfers the memory of the gesture to another domain. The shotgun does not carry out its task by itself. As the Panará claim, one must have a steady and firm arm, a skilful arm.

Distance is a basic element of the hunt. Hunting is always a dynamic of an adequate distance, the ideal relation between two subjects - the distance to kill and not be killed, or the distance to see without being seen, the distance to fire the projectile (arrow or shell, each with its respective distance) without losing sight of it. In terms of distance, the shotgun promotes transformations and creates risks. Firearms connect distant positions within a dynamical field - the potency of movement, the behaviour of the animal, and the obstacles in the environment. The relation between the animal and the type of weapon is fundamental, as is the medium in which it is found (water, air, land).

\footnotetext{
11 As to the firearms used by the Panará today, it is worth describing their properties so that the reader can gauge what sort of weapons they are. For the most part, these are long weapons with a smooth bore, which fires shells - plastic tubes which contain lead projectiles and explosive material at its base. They are classified as 'shotguns', and this is the name that the Panará use when speaking in Portuguese (espingarda). There are also other "shotguns", which in Brazil are known as 'rifle' or fuzil (fusil), which are long weapons with rifling, which the Pananrá call “espingarda 22”, or just “22” (22 calibre). These are semi-automatic or automatic weapons that use so-called "bullets", a compact mass of lead, which are generally reloaded through a clip (which the Panará call sonkiotit, the same word they use to refer to the 'throat'). Smooth-bore shotguns are also known as cartucheiras, and are simple breech-loaders.
} 
Some of the advantages of firearms are their efficacy and lethality, which the Panará understand in terms of the time and energy spent in a hunt, which are transformations of a bodily posture (movement) that is found in other dimensions of life. According to a renown archer, the shotgun is best because it kills faster. It annihilates the animal, which eliminates the need to track it until it dies, and affords more opportunity for killing new animals.

The weapon is always linked to the body of the hunter in such a way as to facilitate walking and shooting. But one thing is important: one must take care when carrying a loaded shotgun. The Panará told me of accidents between friends who were walking through the forest - almost always in a single file, along a straight path - when a shotgun belonging to someone who walked near the back got caught in a branch and fired on the hunter directly in front. This is one of the reasons that Teseia, an old man around 70 years of age, tells me that shotguns are much more dangerous than arrows. Since hunters often set out in company, those who walk towards the back carry an unloaded weapon, holding on to a shell.

There is one further implication concerning the functioning of shotguns that is fundamental: the price of ammunition. During the hunt, ammunition is always a scarce object. It can be claimed that, in a way, shells and arrows are equivalent: the hunter can always find himself with scarce arsenal. The difference is that arrows are produced by the hunter, shells have to be purchased; and purchasing them requires that relations with the whites be established and maintained. Calculations balancing the cost of the shells and the number and quality of prey will vary. There is tendency to privilege larger prey, which implies longer hunts and greater precision with the shotgun. Hunters get frustrated with missed shots. Money's fungibility implies constraints to the activity and thus have a significant impact on the technical system.

\section{Aton! Weapons as sounding devices}

The general term for firearms is aton. The term was explained to me via a comparison made by the Jotikiã. He said that aton designates explosions, like fireworks, which are called atonakriti, which means something like "large explosion".

In a study of the weapons used by Amazonian groups, Raymond Hames (1979) noticed that Yekuana hunters understand the differences stemming from the sound of the firearm as a transformation in their relation with prey $^{12}$. We find the same understanding among the Panará. The Panará distinguish their firearms by two terms: sonkré pãja and sonkré insia, which refer to the universe of sound. The first term designates 12 and 16 gauge firearms; the latter distinguishes those that use bullets, such as a 22 gauge rifle. Sonkré is one of the words for 'voice'; sonkré pãjã is a thin voice while sonkré insia is a gruff voice. Once, when I was speaking to an old woman, I asked her about the terms and she proceeded to classify most of the men of the village in one category or the other. In what pertains to firearms, the classes designate those that emit a loud and high sound and those that emit a low and weak sound. The distinction is basically between shotguns that fire shells and the 22 rifle, which fires bullets and emits a more silent explosion. 12, 16 or 20 gauge weapons produce a blast in the forest. But classifying a weapon as sonkré insia, certain attributes follow: the weapon emits a loud and high potent sound; the shells are large, as is the barrel, like a throat that produces a low sound. The opposite is implied by sonkrép paja

We see that shotguns are connected to one of the central elements of the dynamic of the hunt, which is tied to the properties of its functioning. Sound is crucial to hunting, and it is connected to the actions of the prey. The shotgun generates a medium that is associated with it, much like all technical objects (Simondon 2017; Sautchuk 2019). A sure sign of this medium is auditive, or sonorous. Hunting is an eminently sonorous

12 According to the author: "The blast of a shotgun will usually scatter most animals within earshot, which is one of the reasons why the Ye'kwana hunt small game only when they have failed to find traces of large game: they do not want to scare large game with the report of their guns" (Hames, 1979: 228). 
activity, marked by the generation of silences and by the careful ear of the hunters. One of messages most often sought out is transmitted by sounds coming from the forest's horizon, generated by movement or emitted by the animal itself. Other communications are established, such as that of birds which appear in the presence of certain mammals. Along with odours and aromas, sounds are manifestations of the animal that the hunter is tracking in a space in which sight is compromised by the many layers of light and vegetation.

When I mentioned the absence of women during the hunt, some Panará told me that they used to accompany hunters, but that after the adoption of the shotgun this became more difficult. With the noise of shotguns, animals tend to flee and hunters must chase them, leaving women alone in the forest. Others told me that hunting was always the business of men, "women make kiampo", manioc bread on the pakova leaf. Indeed, some reports point to a significant transformation. With arrows, the old men say, killing prey was silent and many individuals of a herd of peccaries or a troop of monkeys could be killed before they dispersed and fled. But when the shotgun sounds, dispersal immediately follows. Running after the animals is hence a regular development of the hunt, which raises other risks, such as stepping in holes, tripping over stumps, encountering snakes during the chase. All of these risks were mentioned to me. They are perhaps one of the reasons that young people claim that hunting is very difficult.

The acoustic dimension of the weapon thus implies the associated medium of the forest, which, we will now see, is also constituted by other processes. The weapon as much as the ways of moving through the forest are important operational behaviours that define the properties of beings in relation to the hunt.

\section{On modes of hunting}

Attention to Amazonian bodily regimes has produced considerable ethnographic and theoretical advances in the region (Seeger et al. 1979; Vilaça 2002; Fausto 2007). The importance of fabricating the body, its metamorphosis, instability, or embodied knowledge, are fundamental aspects of the analysis of Amerindian sociologies and cosmologies, characteristics of the person, of groups and humanity. An influential theory has been proposed by Viveiros de Castro (1996), who understands the body as "bundle of affects and capacities", the character of which is more performative than given, and where differences lie in ways of being rather than in bodily morphology. The body is defined in Amerindian sociocosmolgies by its "affects, affections, or capacities that singularize each species as a body: what it eats, how it moves, how it communicates, where it lives, whether it is gregarious or solitary..." (Viveiros de Castro 2002: 380). Nonetheless, a more careful analysis of the attitudinal dynamics of the body, that is, of how it acts in its insertion in the world, remains under-described in Amazonian ethnology.

As we all know, in his classic "Techniques of the body" (2003 [1936]), Marcel Mauss drew attention to the instrumental properties of the body, emphasizing the non-natural character of certain acts that are, precisely, the result of processes of learning. Leroi-Ghouran and A-G. Haudricourt took this perspective forward. With his vitalist perspective, Leroi-Ghouran takes the structure of the body, or, more precisely of human energy, as a way of approaching the activities by means of which humans make themselves in relation to the medium they inhabit (cf. Bidet 2007). In this sense, rhythm allows him to approach the dynamic of the insertion of humans in the world as the very genesis of the social.

Bodily rhythms of the hunt point to the fundamental dimension of technogenesis of this body in movement. Moreover, it points to the relation of walking during the hunt with the emergence of the forest for the hunter. The Panará hunt is not moved by a single rhythm, but by a set of inter-crossing rhythms. In effect, the rhythm of the hunter is given by the movement of the body in relation to other movements, above all that of prey. In this case, the rhythm emerges as a network of places and movements that afford action. As Leroi-Gourhan (2002, p. 117) says: "Rhythms, for the subject at least, create space and time; space and time only exist as they are 
lived while they are materialized in a rhythmic casing. Rhythms also create forms". The Panará walk through the forest by means of trails that are the emerging form of these very rhythms, a network of places and times that favour the actions of the hunt.

The Panará call the hunt by the term suasêri. It indicates walking along a trail, or, as Steve Schwartzman (1988: 69) suggests, to go along a line. The anthropologist provides another expression - kupapapa (sic) - which the Panará are said to use to designate the activity that he translates as "to walk along the ground" (kypa, ground; $p a$ to go, to move). The expression $j y$ ra kuy suasêri $m \tilde{a}$ (I am going to walk/hunt) is most common. If we analyse suasêri, we have: sua = ahead, in front; $s \hat{e}$ = to run; $r i$ = perfective morpheme. In some circumstances, it can describe someone running toward someone else. In the context of the hunt, it conveys the idea of approximation, of surrounding, of pursuit.

Tracking can define this activity, particularly because of its relation to a prey's ways of acting (Descola, 1994; Silverwood-Cope, 1990: 59-60). Observing the paths of animals is much of what a hunter does. But tracking does not capture the complexity of walking during the hunt and suasêri seems to point to other layers of complexity involved in the activity. Without seeking to constrain the term in a stable translation (the Panará have already done this, translating as 'to hunt'; but what is to hunt anyway?), I suggest that when hunters say jy ra kuy suaseri mã they are saying that they are going to walk in the forest looking for animals. Approximating an imponderable, suasêri is movement in relation to/with the animal.

The idea that hunting and walking are similar activities is common to other Amazonian societies (e.g. Aparício 2014; Descola 1994; Rival 2002). Uirá Garcia (2010, 2012a) has carefully developed the idea. Among the Awá, to hunt and to walk are both expressed by the verb watá, and the hunter is a "walker" watá ma'á (Garcia 2010: 54). There is furthermore a relationship between hunting and knowledge, as expressed in the concept of harakwá ("my place", "my domain"). The Awá notion of harakwá does not refer to a territory, but to a territoriality. It is a relational notion of space which does not define a place, but a way of life - a "wayfaring" way of life (as proposed by Ingold, in Garcia 2010: 65). It is a "way of being" related to a territorial support that is not given a priori, but constituted by the relations between people, environment and the beings of the world.

This wayfaring way of being can also be said to be a genetic movement, by means of the many variations in how walking is put into effect. It is along the trail that animals and humans cross each other, or in which their movements are juxtaposed. Once, while narrating a hunt in the inkâ (men's house, or the centre of the village), an old man named Akâ said that one has to identify where animals walk, because "peccaries follow their own path...”. He was explaining to younger listeners that, more than simply following a trail, they return from whence they came. They walk along a trail that is only recognizable by the significant damage that a herd of peccaries causes in the forest - the suasina pjy. The trail (pjy) of peccaries is registered in the forest by their movement. 


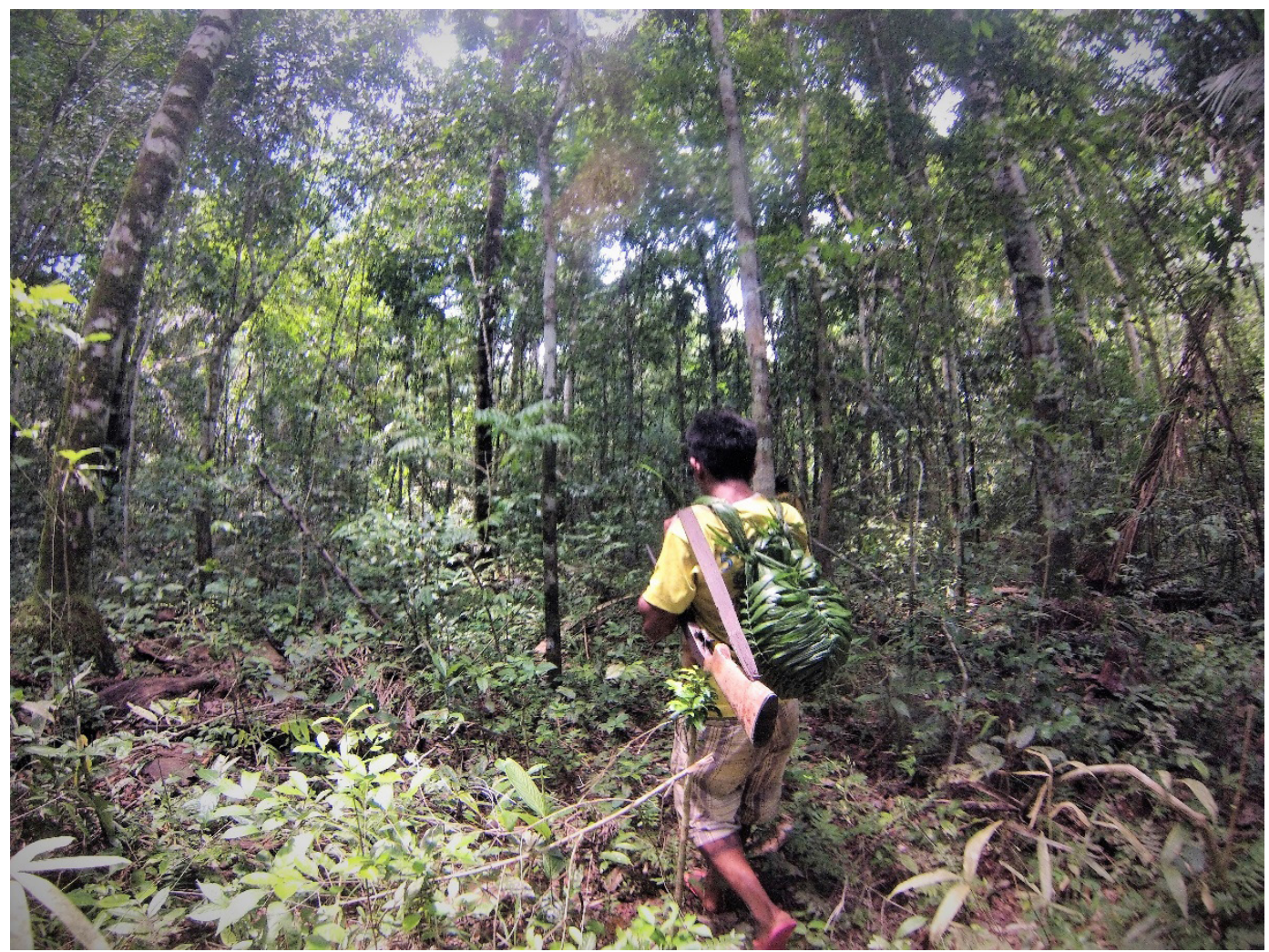

Hunter walks along a narrow path in the midst of vegetation.

He identifies it by slight signs in the landscape. (Photo by the author)

There is, needless to say, a technique to walking. André-Georges Haudricourt (2010:35-48) has drawn attention to the diversity of this almost natural gesture. The Panara pay attention to the singularity of the movements of walking during the hunt when, for example, they reflect on the best clothes for this activity. Until recently, elders condemned the use of pants and sneakers because they created disadvantages in motility and in interacting with the forest. With the increasing and varied use of clothing bought in the city, differences have become more noticeable. They say that the smell of laundry detergent hinders attempts to get close to the animals. I myself noticed that hunting with rubber sandals has many advantages, one of which is that it dries quickly after crossing streams; the other, quite essential, is that they can be easily removed when chasing prey that is in flight.

The ability to move in the forest is learned by young people through successive trips to the forest, as is the resistance required for long walks. Moving through the forest, the gait is silent and agile. When hunters move in groups, they walk in a single file along the path. The man who goes in front carries out the same movements of all hunters: his rhythm is established by all manner of signs. At any sound, odour or sign of movement, the hunter stops and observes in total silence, looking for the origin and characteristics of that sign. This is a constant dynamic. The trail is thus a trajectory interspersed with these movements. A frequency of movement is established in relation to signs of prey.

Sonorous, tactile and aromatic qualities constitute the space of the hunt. Walking is dependent on the texture of the ground, which varies at different times of the year and in different parts of the forest. During my walks with the hunters, I stressed our bodily differences (with a degree of frustration, to be sure). The lightness and agility with which a hunter moves, with a cunning grasp of movement, contrasted with my weight and sluggishness, and with my inadequate proportions along the path. Forest trails are only used sporadically, and they tend to be covered in vegetation, although they remain noticeable to the trained eye. I was surprised every time I tried to follow my hunting partners, walking behind them, and would bang my head, or shoulders or 
arms, in vines, stumps or branches along the way. The trail is not limited to the ground; it is tridimensional, a sort of tunnel through the forest that occupies the space of a body, the body of Panará men. Despite having been called the "giant Indians" at the time of first contact (see Arnt et al. 1998), the average height of Panará men is $1.65 \mathrm{~m}^{13}$. This implies a tridimensional space of more or less that stature along the hunting trails. Nearing $1.85 \mathrm{~m}$ in height, I did not fit into them.

A walk is made up of constant changes in direction, velocity and bodily position. One must crouch, jump, overcome obstacles, such as anthills that can create a large tract along the way. The hunter's gait is therefore oriented towards the front and the ground in a correlation of visual and tactile perception, without cutting off the other senses. At the same time, the hunter checks the horizon in search of animals (in the trees, in the visible space between the canopies, or penetrating the sounds of the forest) and takes care with his movement, observing the floor for tracks left by animals. The walk conveys a sense of familiarity with the environment, which involves both the memory of places visited and the effect of this knowledge diffused in places.

An aspect of the relation between knowledge and environment is to be found in the sounds of the forest. One time, talking in front of a house, I overheard a husband say to his wife, "îkjẽ hẽ ka sam pá pee ri", "I will go outside to listen". This interesting expression foregrounds the essential characteristic of the activity. As I claimed above, hunting is a noisy activity and its rhythm and frequency is put into effect by the interplay of movement and rest along the way to listen to the sounds of the forest. This forest biophony that the hunters listen to is the object of great attention and consideration. Older hunters are sophisticated observers of birds, for example, reproducing many of their sounds. I was once walking with Parikiati, an experienced hunter, one of the few who sometimes went to hunt with his dog ${ }^{14}$, and he would stop frequently to observe nests and the flight of birds, finding great pleasure in encountering these small animals. Parikiati's sophisticated ornithology sees birds as fundamental agents in the hunt.

Tim Ingold (2015:208) observes that sound is "that in which we hear", which means that the perception of prey during the activity occurs through the medium of sound, and not in an atmosphere of silence. Panará hearing is sharp during the hunt, where we find a "sonorized" body - that is, a body vibrating by the sounds of the forest. The need to reduce conversations and to act in silence does not remove the sound of the hunt, but transforms the nature of the relation maintained with it. Uirá Garcia (2016) is right to draw attention to an ethnography of "the silence, the calls, the moaning, the imitations, and other non-verbal aspects" in order to understand "complex systems of knowledge, with knowledge practices that can only by studied in action".

It is worth noting that, when taken as a singular body dynamic, hunting walks are in close relation to other activities of the Panará. Log racing is foremost among them. Although less common at present, log racing used to be carried out daily in villages, making possible highly desirable strong and firm (si tâti) bodies, aspects of beautiful (ikiin) people. Log racing involves two activities: running and carrying a large and heavy log (usually of the buriti palm), much like a hunter ably carries large prey tied with leaves to their body. At present, soccer sometimes does the work of this practice, particularly in what pertains to speed and agility. Soccer is also an art of velocity among the Panará. Converging the strength of log racing to the speed of hunting, soccer resumes a moment of the production of the body that is very important for various Indigenous groups (cf. Vianna 2008). On most given afternoons, on the side-lines of the pitch, elders sit to watch the game, yelling at the players "Suasê! Suasê!", a way of encouraging them to run towards the ball or the opponent.

\footnotetext{
13 As I was able to confirm in the records of the Sanitary District. "Gigantism" is a Panará ideal, and in the past tall men (up to 2.oo.) were renown as "beautiful". At any rate, the label of "giant Indians" became a recurring trope among those working on the contact front. It also circulated in the national and international press and fed into the exotic imagery that pervades perceptions of Amazonia. For a sample of these images, Arnt et al. (1998) is an excellent source. See also the work of Adrian Cowell (1974).

14 Unlike many Indigenous peoples, the Panará do not make intensive use of dogs during the hunt. For an example of the relation between dogs and hunters in Amazonia, see Vander Velden (2012).
} 
Most of the times that I went hunting, I accompanied traditional partners, who were my Panará brothersin-law or brothers. We left by boat at dawn, traveling either up- or down-river, in groups of three or four hunters. In a known locale we would dock our boat and enter the forest walking quickly along the trail. In general, we would find peccary herds or troops of monkeys. The encounter between these two collectives (a group of hunters and a herd of animals) and the actions that followed always reminded me of a sort of hunting blitzkrieg, a scathing melee in which we sought to kill as many individuals as possible. The rapid and fatal action was effusive and intense. It thus contrasts with another hunt, that I saw being carried out by older and more experienced men. These hunts are generally carried out by a lone hunter, in long journeys in search of large prey, with careful tracking, a wide variety of felled prey, and where diverse and abundant knowledge is put into practice. The rhythm is also different, and we may say that the hunt is, in this case, more extensive, in contrast to the intensity of the blitzkrieg of younger hunters.

This opposition corresponds to the categories of kowmokiara and topytumara, that is, the youth, those of "now", and the elders, or experienced men. The opposition between youth and the elderly is pervasive to various dimensions of Panará social life, and constitutes an important dualism for them (cf. Ewart 2013: 68). Soccer teams are usually distinguished by this opposition in village games, and it is only to be expected that it also be manifested in the differential rhythms of the hunt.

\section{Chasing Fruits in the Forest}

Since hunting is an articulation, proposed by the hunter, between his action and that of the animal, the tracks of prey through the forest are key. These are properties of the "proper-worlds" of the animals, or, to use the term proposed by Jakob von Uexkull (1982), their umwelt, which is the meaningful environment of an organism. According to Uexkull, an umwelt exists for the animal given its morphology, sensibility, and potentiality. The environment is imbued with meanings that exist according to the perceptive apparatus and the acts of animals (cf. Ingold, 2015: 131-132). By penetrating into the sounds (or odours, for example) of prey, hunters access their umwelt; by follow their trail, their tracks, they do so as well.

Every animal has its trail in the forest and its proper-world has its scales, velocities, distinct vectors. Much of skills for hunting emerges from the relation with the different trails made by the animals. Suaseri, therefore, involves approaching, or tracking, the meaningful world of the animal, which provides a means for the hunter to find it. Panará hunters sometimes call the trails of animals pá kom (where it goes on its feet). A tortoise drags through the foliage during the rains, when it walks through the forest. Peccaries, walking in large herds, leave tracks on the earth and overturn leaves. Animal stool is also a sign of their behaviour. Arboreal animals such as birds and monkeys leave behind other signs, mostly the remains of fruit.

The trail of the animals is not necessarily the trail of the hunter, and once the tracks are found, the hunter will follow it, depending on his chances for a kill. The fact that animals have their trails and that these cross the trails of hunters conjures a web of movements in the forest, in which the hunter finds himself. Awareness across proper-worlds, however, can only come about through a passage in modes of perception, wherein the hunter seeks to approximate animal perception. The effort resides in overcoming, or generating an approximate relation, between two dynamics (animal and human), in a situation that turns out to be favourable for the hunter. Generating a synthesis that keeps human and animal separate, putting one in a condition to surprise the other. How do they go about this?

Like most, if not all, forest people, the Panará do not walk through the forest willy-nilly. Where there is no trail, one must be made. Trails are the main reference for movement. Bruce Albert and François-Michel Le Tourneau (2007) carried out research on Yanomami forest trails, making use of local cartography and geoprocessing tools. They begin with a critique of the idea of concentric zones that expand from areas of 
more intense use to those that are less utilized, which has generally been implicitly assumed in analyses of Indigenous resource use. For the authors, "the Yanomami ethnogeographic organization of space appears to be reticular-structured by a crisscrossing network of sites (points) and routes (lines) - rather than zonal" (ibid: 584-585). The space utilized thus seems to contain lacunae, to be discontinuous, diffuse, and hence different form the zonal model that suggests the total exploitation of the area in each zone. Furthermore, the models contrast between a "timeless topography" and a "topology of changing webs". Panará hunting trails are similar to this model.

Inkjown kin! say the Panará of the good forest, one with many fruits, where animals gather, where there are monkeys, tapirs, tortoises. The Panará like to hunt in this forest. Trees are not too tall, the underbrush is low, it is not dirty (intepi), which is to say, thick. But when hunting, the hunter walks through many landscapes, among which there are those that are suitable for one type of prey or another. One of area which gathers many animals, and which is often sought out by hunters, are the salt licks, which the Panará call sõkwê.

Salt licks are depressions in the forest, with little vegetation and humid soils. The Panará identify salt licks as the home of peccaries (suasina jõ kwa), tapirs and deer; or as things of these animals (- jõ soti), as a Panará told me once, drawing an analogy with those things that are Panarájõ soti - that is, 'culture', according to their translation (cf. Ewart 2013). These places are made up of sandy soils that contain a large quantity of minerals. They are visited by animals who consume the soil (geophagy) for mineral supplements for their diet ${ }^{15}$. It is a basic component of the habitat of various species.

In another formulation, salt licks are "familiar places", as Anna Tsing calls spaces where multispecies interactions occur, and which are recognized by foragers (Tsing 2015). Rather than a specific place, which territorializes a species, it is a landscape of multiple residents and visitors. The fact is that in salt licks, against any human exceptionalism, the hunter uses the configuration of agents for his activity. This interdependency favours predation.

In his study of the Ávila Runa of Ecuador, Eduardo Kohn (2013) investigates the configurations of limits to the possibility for action that emerge in the Amazonian rainforest, and how they come to matter for people. He argues that certain forms that appear in nature - Kohn's example concerns Hevea groves and their distribution in certain patterns in the forest, in relation to water courses, and in terms of how the colonial interest in rubber made use of such patterns - are harnessed by the living, thereby enabling the efficacy of certain activities. The regularity of these emerging forms is, however, nested in other processes (Kohn 2013: 167). Kohn's analysis applies to the Panará case, particularly because of an example that Kohn uses to illustrate the harnessing of these forms that propagate throughout the forest. This example cuts across, precisely, the relation between hunters and animals. Allow me to quote him at length:

Because of the high species diversity and local rarity of species and the lack of any one fruiting season, the fruits the animals eat are highly dispersed in both space and time. This means that any given time there will exist a different geometrical constellation of fruiting resources that attracts animals. Fruit-eating animals amplify this constellation's pattern. For they are not only attracted to fruiting trees but often also to the increased safety provided by foraging in a multispecies association. Each member "contributes" its species-specific abilities to detect predator - resulting in a greater overall group awareness of potential danger. The predators, in turn, are attracted to this concentration of animals further amplifies the pattern of distribution of life across the forest landscape. This result in a particular pattern of potential game meat: a clustered, shifting, highly ephemeral and localized concentration of animal interspersed by vast areas of relative emptiness. Ávila hunters, then, don't hunt animals

15 Salt lick soils are generally composed of sodium and iron. These mineral elements can also be found in river banks and other chemical compositions, such as clays, which are also sought by animals. Biological studies show that these areas are visited by a vast range of species in Amazonia, among which are primates, ungulates, birds, bats, and certain arthropods (Dudley, Kaspari and Yanoviak 2012). The vertebrates leave behind tracks which indicate intensive and constant movement through these areas. 
directly. Rather, they seek to discover and harness the ephemeral form created by the particular spatial distribution or configuration of trees species that are fruiting at any given point in time because this is what attracts animals (Kohn 2013:163-164, references removed).

The Panará also hunt animals by taking into account similar patterns in the distribution of fruiting trees. The effect of this may be called an aesthetic of the hunt, which is visible in the forest, particularly in the network of trails in which hunting takes place. Rather than a form applied to an amorphous forest, the trail is a trajectory that helps to modulate action and perception in relation to the life fluxes that disperse throughout the forest. It propitiates certain properties of the forest, properties of the life fluxes that circulate through it. This can be seen in the Panarás sophisticated differentiation of the forest landscape, distinguishing a combination of light, vegetation and animals. The good forest, as they call it, is easy to walk through and has fruiting trees. Hunters enjoy walking through this forest.

In the ontogenetic system of the hunt, prey is directly implicated in the irradiation of trails, and therefore in the gesture and rhythm of walking during the hunt. The reticulation of the trails fit the gestures, acts and perceptions that circulate through it, constituting the means by which prey presents itself. In another field of the action, prey cross the paths of the Panará, stressing the relation that they create in the hunt.

The Panará have a set of procedures, that we might call effective acts of a shamanic nature, that seek to modulate the actions of hunter and prey. Lack of space prevents me from discussing them here in detail, but it is worth noting that, as argued by Warnier (2009), these technical procedures are effective both on prey and on hunters, making them dream, for example. They involve hunters manipulating elements such as flowers, fingernails, ashes, flies, and so on, that possess either a resemblance or a contiguity of some sort with the animal that is to be hunted, and which aim to act on it from a distance ${ }^{16}$. One of their effects on the prey as that it "turns itself in along the trail", as they say.

This is a paroxysm of the relation between the hunters actions, the trail and the prey. The Panará also hold shamanic negotiations to mobilize the owners of the animals, which are spirits of the dead, so that they can contribute to the hunt. Shamanic songs and rites are ways of mobilizing the kin of the dead so that they open the gates of their farms, releasing their creatures to be killed, as the Panará shaman Sykiã once told me. The domestic animals of the owners of prey is a well-known phenomenon in Amazonia (see Descola 1994; Fausto 2008; Kohn 2013). The important Panará inflection to this widespread feature is that these owners are dead kinspeople, who remain close allies of the hunters. In these situations, the hunter will again find the animal in his path - exactly where his kinsperson left it.

The trail is hence not a mere route through the layers of soil in the forest. The signs and marks that hunters make as they move do, of course, produce a preferential trajectory, through which he can return. But the trail is also a trajectory that propitiates action, and through which an encounter with prey is ensured. Other encounters are possible - one may chase after a fleeing animal and find another which can be killed, for instance. This is only one further variation to the activity of hunting. The trail remains the place where he finds his prey, and where he finds his home. It is along it that the transformation of the hunt occurs, as does the transformation of the hunter; and finally, the transformation of animal into meat.

16 See Schwartzman (1988) a presentation of many of these procedures, which he calls "hunting magic". 


\section{Conclusion: person and territory among the Panará}

The set of operations that I have described in this article constitute a wide field of action during the hunt, which enables us to follow the activity through elements of its technical system. I have focused on what emerges as important to the Panará when carrying out this activity: the relation between the hunter and his technical object and the relation between perceptions and abilities of the hunter, and ways of interacting with the forest. Through an analysis of the technical relations, we have followed how the hunter individuates himself - that is, how he constitutes his operational bundle, his technical morphology. Yet the pole in which the activity is concentrated is fundamental to this individuation - that is, the prey chased by the hunter, in the terms in which his individuation occurs, where the predator-prey relation is implicated.

Investigations of this sort can point to an aspect which, it seems to me, is crucial for the relationship between anthropology and Indigenous people: how to describe and accompany their regimes of territoriality, i.e., they means by which these people know and dwell in the territory, or the land (terra) as they have come to call it (cf. T/terra 2017). These means occur through sophisticated and original regimes of knowledge, which differ from the ontological framework of naturalist science. But it is not just knowledge, but what we can convey as modes of inhabiting, means of living through their experiences in the land - forms that anthropology of technique allow us to access.

What I have described of the weapons and the person of the hunter - his body and actions - and the forest that emerges in the hunt - the trails that cross fates - are two elements that take us along the path that the Panará make, just as they make their land in the appropriate place, land that they possess and which possesses them (which is very different from saying that they are its proprietors). This takes us to a further conclusion: that hunting is a process of ontogenesis that leads to the constitution of the person (particularly, but not only, the male person) among the Panará. I have shown this ontogenesis through the analysis of a technical system. To conclude, I offer a short comparison, which perhaps will afford us with an explanatory contrast.

For the Panará, the hunter is a person imbued with values that are judged ideal for a marital relation. That is, the hunter is a good husband, and good husband is a hunter. Both positions self-reproduce, that are processes that are constituted mutually. A good husband is also a good father, someone who produces husband-wife and father-son relations at the same time as he is produced by them, that is, made by continuous acts of feeding and care, which necessarily affect his success in the hunt. This dynamic, however, is the object a new inflection, which, to be sure, has been occurring for some time. I am referring to a new individuation, particularly of Panará men, which concerns their relation with the special schools that exist in the village. The teacher is, hence, part of another ontogenesis, part of a different experience, which involves two central elements: the Portuguese language (spoken and written) and money. As younger Panará women often told me, the ideal husband is no longer the hunter, but the teacher.

This comparison takes us into a set of questions that I will have to analyse elsewhere. But it allows us to see the constitution of the person in relation to a set of elements, by means of which a technical relation is instated, if we understood them within the framework I develop here, as transitive ways of acting with the matter of the world. The centrality of the hunt or the school in the Panará universe is connected to a social topology within which animals, whites and their territories, cities and the forest, are all distributed. A technical analysis of this field will allow us to approximate the lived experience of the Panara with those of other Amazonian peoples, no longer seeing hunting as a mere baseline for the reproduction of their material survival; or as the survival of a practice destined to disappear. 
Submitted: August 28, 2018

Accepted: November 24, 2018

Translated by: Luiz Costa

\section{References}

ALBERT, Bruce; LE TOURNEAU, François-Michel. 2007. "Ethnogeography and Resource Use among the Yanomami: Toward a Model of 'Reticular Space'”. Current Anthropology, 48(4): 584-592.

ALMEIDA, Mauro Barbosa. 2013 “Caipora e outros conflitos ontológicos”. R@u: Revista de Antropologia da UFSCar, 5: 7-28.

APARÍCIO, Miguel. 2014. "Relações Alteradas - Ideias Suruwaha sobre Animais e Caça”. Ilha. Revista de Antropologia, 16(2): 37-68.

ARNT, Ricardo; PINTO, Lúcio Flávio; PINTO, Raimundo; MARTINELLI, Pedro. 1998. Panará: A volta dos índios gigantes. São Paulo: Instituto Socioambiental.

BATISTA DE LIMA, Daniela; BECHELANY, Fabiano. 2017. "O descaso induzido: o desterro dos Tapayuna e dos Panará”. Mediações - Revista de Ciências Sociais, 22: 179-203.

BECHELANY, Fabiano. 2012. "Ideologia Venatória na Amazônia: notas sobre a caça na etnologia das terras baixas da América do Sul". Espaço Ameríndio, 7(1): 310-344. . 2017a. Suasêri: a caça e suas transformações com os Panará. Tese de Doutorado, Programa de Pósgraduação em Antropologia Social, Universidade de Brasília - Brasília. . 2017b. '“Flecha é igual 22': gesto técnico e transformação no arsenal de caça dos Panará". In: Carlos Sautchuk (org.), Técnica e Transformação: perspectivas antropológicas. Rio de Janeiro: ABA Publicações. pp. 265-292.

BIDET, Alexandra. 2007. “Le corps, le rythme et l'esthétique sociale chez André Leroi-Gourhan” Techniques \& Culture, 48-49: 15-38.

COELHO DE SOUZA, Marcela. 2002. O Traço e o Círculo: o conceito de parentesco entre os Jê e seus antropólogos. Tese de Doutorado, PPGAS/Museu Nacional/Universidade Federal do Rio de Janeiro - Rio de Janeiro. COSTA, Luiz. 2012. "Making animals into food among the Kanamari of western Amazonia". In: Marc Brightman; Vanessa Grotti; Olga Ulturgasheva (eds.), Animism in Rainforest and Tundra: Personhood, Animals, Plants and Things in Contemporary Amazonia and Siberia. 1ed. New York: Berghahn. pp. 96-112. COUPAYE, Ludovic. 2015. "Chaîne opératoire, transects et théories: quelques réflexions et suggestions sur le parcours d'une méthode classique". In: P. Soulier (ed.), André Leroi-Gourhan: "l'homme, tout simplement". Paris: Éditions de Boccard - Travaux de la MAE. pp. 69-84. .; DOUNY, Laurence. 2010. "Dans la Trajectoire des Choses: comparaison des approaches francophones et anglophones contemporaine en anthropologie des techniques". Techniques \& Culture, 52-53: pp 12-39. .; PITROU, Perig. 2018. "Introduction. The Interweaving of Vital and Technical Processes in Oceania". Oceania, 88: 2-12.

COWELL, Adrian. 1974. The tribe that hides from man. New York: Stein and Day.

DAMATTA, Roberto. 1973. “Panema”. In: Ensaios de Antropologia Estrutural. Petrópolis: Vozes. pp. 63-92.

DE LA CADENA, Marisol. 2015. Earth Beings: ecologies of practices across Andean worlds. Durham: Duke University Press.

DESCOLA, Philippe. 1994. In the society of nature: a native ecology in Amazonia. Cambridge: Cambridge Univ. Press. 
1998. "Estrutura ou sentimento: a relação com o animal na Amazônia”. Mana, 4(1): 23-45.

DUDLEY, R.; KASPARI, M.; YANOVIAK, S. P. 2012. "Lust for Salt in the Western Amazon". Biotropica, 44(1):

6-9.

EWART, Elizabeth. 2005. "Fazendo pessoas e fazendo roças entre os Panará do Brasil Central". Revista de Antropologia, 48(1): 9-35.

. 2013. Space and Society in Central Brazil: A Panará Ethnography. London/ New York: Bloomsbury.

FAUSTO, Carlos. 2007. "Feasting on People: Eating Animals and Humans in Amazonia”. Current

Anthropology, 48(4): 497-530.

. 2008. "Donos Demais: Maestria e Propriedade na Amazônia". Mana, 14: 280-324.

FERRET, Carole. 2014. "Towards an anthropology of action: From pastoral techniques to modes of action". Journal of Material Culture, 19(3): 279-302.

GARCIA, Uirá. F. 2010. Karawara: a caça e o mundo dos Awá-Guajá. Tese de doutorado. Depto. de Antropologia Social. FFLCH/USP. São Paulo.

. 2012a "Ka’á Watá, “andar na floresta”: caça e território em um grupo tupi da Amazônia”. Revista

Mediações, 17: 172-19o.

. 2012b. "O funeral do caçador: caça e perigo na Amazônia”. Anuário Antropológico, II: 33-55.

2016. "Caça (Verbete)". Teoria e Cultura, 11: s/n.

GOW, Peter. 1989. “The Perverse Child: Desire in a Native Amazonian Subsistence Economy”. Man, 24(4): pp. 567-582.

GRENAND, Pierre. 1995. “De l'arc au fusil : un changement technologique chez les Wayapi de Guyane”. In: F. Grenand; Randa (eds.), Transitions plurielles: examples dans quelques sociétés des Amériques. Paris: Peeters.

pp. 23-53.

HAMES, Raymond B. 1979. "A comparison of the efficiencies of the shotgun and the bow in neotropical forest hunting”. Human Ecology, 7(3): 219-252.

HAUDRICOURT, André-Georges. 2010. Des gestes aux techniques: essai sur les techniques dans les sociétés prémachinistes. Paris: Maison des Sciences de l'Homme/Editions Quae.

HUGH-JONES, Stephen. 1996. "Bonnes raisons ou mauvaise conscience? De l'ambivalence de certains Amazoniens envers la consommation de viande". Terrain. Anthropologie \& Sciences Humaines, 26: 123-148.

INGOLD, Tim. 200o. The perception of the environment: essays on livelihood, dwelling and skill. London: Routledge. . 2015. Estar vivo: ensaios sobre movimento, conhecimento e descrição. Petrópolis: Vozes.

KENSINGER, Kenneth. 1983. "On meat and hunting". Current Anthropology, 24(1): pp. 128-129.

KIRKSEY, Eben; HELMREICH, Stefan. 2010. “The emergence of multispecies ethnography”. Cultural Anthropology, 25 (4): 545-576.

KOHN, Eduardo. 2013. How forests think: toward an anthropology beyond the human. Berkeley, Calif.: Univ. of California Press. . 2015. "Anthropology of Ontologies". Annual Review of Anthropology, 44(1): 311-327

LAGROU, Els. 2018. "Copernicus in the Amazon: ontological turnings from the perspective of Amerindian ethnologies". Sociologia e Antropologia. 8(1): 133- 167.

LEMMONIER, Pierre. 1992. Elements for an Anthropology of Technology. Ann Arbor: Museum of Anthropology, University of Michigan.

LEROI-GOURHAN, André. 1984a [1943]. Evolução e Técnicas: I- O homem e a matéria. Lisboa: Edições 70. . 1984b [1945]. Evolução e Técnicas: II- Meio e Técnicas. Lisboa: Edições 70. 1990 [1964]. O gesto e a palavra: 1 - Técnica e Linguagem. Lisboa: Edições 70. 2002 [1965]. O gesto e a palavra: 2 - Memória e ritmos. Lisboa: Edições 70. 
LIMA, Tania S. 1996. "O dois e seu múltiplo: reflexões sobre o perspectivismo em uma cosmologia tupi”.

Mana, 2(2): 21-47.

MARVIN, Garry. 2010. “Challenging animals: project and process in hunting.” In: S. Pilrgim; J. Pretty (eds.). London: Earthscan Publications. pp. 143-159.

MAUSS, Marcel. 2003 [1936]. "As técnicas do corpo". In: Sociologia e antropologia. São Paulo: Cosac \& Naify. pp. 399-422.

MURA, Fabio. 2011. "De sujeitos e objetos: um ensaio crítico de antropologia da técnica e da tecnologia". Horizontes Antropológicos, 17(36): 95-125.

RIVAL, Laura. 1996. "Blowpipes and spears: the social significance of Huaorani technological choice". In: P. Descola; G. Pálsson (eds.), Nature and society: anthropological perspectives. London: Routledg. pp. 145-165. . 2002. Trekking through history: the Huaorani of Amazonian Ecuador. New York: Columbia Univ. Press. . 2012. "The materiality of life: Revisiting the anthropology of nature in Amazonia". Indiana, 29: $127-143$.

SANTOS-GRANERO, Fernando (org). 2009. The occult life of things: native Amazonian theories of materiality and personhood. Tucson: University of Arizona Press.

SAUTCHUK, Carlos E. 2015. “Aprendizagem como gênese: prática, skill e individuação”. Horizontes Antropológicos, 21: 109-139.

. 2019. "The pirarucu net: artefact, animism and the technical object". Journal of Material Culture, 24(2): 176-193.

SCHWARTZMAN, Steve. 1988. The Panara of the Xingu National Park: The Transformation of a Society. PhD Thesis, Department of Anthropology, University of Chicago - Illinois, Chicago. . 2010. "Nature and Culture in Central Brazil: Panará Natural Resource Concepts and Tropical Forest Conservation". Journal of Sustainable Forestry, 29(2-4): 302-327.

SEEGER, Anthony; DAMATTA Roberto; VIVEIROS DE CASTRO, Eduardo. 1979. "A construção da pessoa nas sociedades indígenas brasileiras". Boletim do Museu Nacional, 32: 2-19

SHEPARD, Glenn H. 2014. "Hunting in Amazonia". In: H. Seline (orgs.), Encyclopaedia of the History of Science, Technology, and Medicine in Non-Western Cultures. 7ed.: Springer Netherlands. pp. 1-7.

SIGAUT, François. 1991. "Un couteau ne sert pas a couper mais en coupant. Structure, fonctionnement et fonction dans l'analyse des objets". In: 25 ans d'études technologiques en préhistoire, Bilan et perspectives. Juan-les-Pins: Éditions APDCA. pp. 21-34. . 2008. Gestes et apprentissage. (Manuscript). Available in http://www.francois-sigaut.com/index.php/ inedits/52-articles-inedits/487-2008-5. Accessed June 1, 2019.

SILVERWOOD-COPE, Peter. L. 199o. Os Makú: povo caçador do noroeste da Amazônia. Brasília, Distrito Federal: Editora UnB.

SIMONDON, Gilbert. 2005. L'individuation à la lumière des notions de forme etd'information. Grenoble: Millon. . 2017 [1958]. On the Mode of Existence of Technical Objects. Minneapolis: Univocal Publishing.

TAYLOR, Anne-Christine 2001. "Wives, Pets and Affines: Marriage among the Jivaro". In: L. Rival; N. L. Whitehead (eds.), Beyond the visible and the material: the amerindianization of society in the work of Peter Rivière. Oxford: Oxford Univ. Press. pp. 45-56.

TSING, Anna. 2015. “Margens Indomáveis: cogumelos como espécies companheiras”. Ilha. Revista de Antropologia, Florianópolis, 17(1): 177-201.

$\mathrm{T} /$ terra. 2017. “T/terras indígenas e territórios conceituais: incursões etnográficas e controvérsias públicas". Entreterras, 1(1): 6op.

UEXKÜLL Jakob von. [1958]1982. Dos Animais e dos Homens: Digressões pelos seus mundos próprios. Doutrina do Significado. Lisboa: Livros do Brasil. 
VANDER VELDEN, Felipe. 2012. Inquietas companhias: sobre os animais de criação entre os Karitiana. São Paulo: Alameda Casa Editorial.

VIANNA, Fernando Luiz Brito. 2008. Boleiros do Cerrado - indios Xavantes e o futebol. São Paulo: FAPESP/ISA/ Annablume.

VILAÇA, Aparecida. 2002. "Making Kin Out Of Others In Amazonia”. Journal of the Royal Anthropological Institute, 8(2):347-365.

VIVEIROS DE CASTRO, Eduardo. 1996. "Os pronomes cosmológicos e o perspectivismo ameríndio". Mana, 2(2): 115-144. . 2002. A inconstância da alma selvagem: e outros ensaios de antropologia. São Paulo: Cosac \& Naify.

WARNIER, Jean-Pierre. 2009. “Technology as efficacious actions on objects... and subjects”. Journal of Material Culture, 14(4): 459-470.

\section{Fabiano Campelo Bechelany}

Department of Social Science of Araguaia-Tocantins

Federal University of South and Southeast Pará

https://orcid.org/00oo-0002-9414-6312

E-mail: fabianobechelany@gmail.com 